\title{
Modification of flavor preference by olfactory preexposure in normal and zinc-sulfate- treated mice
}

\author{
ANTHONY COOPER and SUZETTE HATHORN \\ Miami University, Oxford, Ohio 45056
}

\begin{abstract}
Mice treated at 14 days with $2 \% \mathrm{ZnSO}_{4}$ intranasally and controls were exposed for $1 \mathrm{~h} /$ day between Days 14 and 21 either to an air stream with a peppermint odor or to one containing ethyl alcohol. Their diet preference was recorded for 5 days between Days 28 and 32 . Exposure to peppermint resulted in a heightened preference for peppermint-flavored diet on Days 2 and 3 of testing. Treatment with $\mathrm{ZnSO}_{4}$ did not influence this preference, although the treated animals showed a temporary reduction of body weight.
\end{abstract}

It has been known for some time that preexposure of rodent pups to artificial (i.e., biologically insignificant) odors may lead to later responsiveness toward those odors (Carter \& Marr, 1970; Mainardi, Marsan, \& Pasquali, 1965; Marr \& Gardner, 1965; Porter \& Etscorn, 1974). Leon, Galef, \& Behse (1977) have pointed out that the development of such preferences may have been influenced by the presence of the mother and siblings, and have demonstrated that exposure of rat pups in isolation to an arbitrary (peppermint) odor during the first 19 days of life results in a preference for peppermint-flavored diet on Day 21. This interesting result points to the importance of early olfactory experience in determining the later food preferences of rats and suggests that this may not result from the odor having acquired secondary reinforcement properties.

The present experiment is designed to ascertain whether a limited exposure to peppermint odor between 14 and 21 days of age leads to modified diet preference in mice, and to examine the effects of intranasal treatment at Day 14 with zinc sulfate solution [a treatment producing temporary anosmia (Alberts \& Galef, 1971)] on any dietary preference produced by preexposure to peppermint.

\section{METHOD}

Mice of the inbred $\mathrm{A} / \mathrm{J}$ strain were used in the experiment; when the subjects were born, they were randomly assigned to mothers and reared in litters of four to seven pups. At 14 days of age, the pups were assigned to one of four experimental groups. Every litter included pups in at least three of the four groups. At this time, Groups $\mathrm{ZP}(\mathrm{N}=7)$ and $\mathrm{ZC}(\mathrm{N}=8)$ received intranasal injection of $.005 \mathrm{ml} 2 \%$ zinc sulfate solution, designed to produce temporary anosmia (Cooper \& Sosenko-Petro, Note 1). Groups UP $(\mathrm{N}=8)$ and $\mathrm{UC}(\mathrm{N}=7)$ received no treatment. For $1 \mathrm{~h} /$ day, on Days 14-21, the mice of Groups ZP and UP were exposed to a peppermint odor (Frank's peppermint extract). Groups $\mathrm{ZC}$ and UC were exposed in a similar fashion to a control "odor," which consisted of air passing over $65 \%$ ethyl alcohol (the peppermint extract being in $65 \%$ ethyl alcohol). The exposure situation was as follows. The animals were placed in an exposure chamber which was divided into eight cells $(11.25 \times 2.5 \times 7.5 \mathrm{~cm})$, one animal to each cell. The floor and side walls were wooden, the front and rear walls were of fine wire mesh. Placed $7.5 \mathrm{~cm}$ in front of the front wall was a jar $(1.25 \mathrm{~cm}$ deep $\times 5.0 \mathrm{~cm}$ diam) containing $5 \mathrm{ml}$ of the odorant, over which a steady stream of air (approximately $29 \mathrm{cc} / \mathrm{sec}$ ) was passed by means of an aquarium air pump (Second-Nature Whisper 200). The odorized air left the chamber through the rear-wall gauze. When in use, a wooden lid was placed over the entire apparatus; this fitted closely, so the mice could not climb out of their cells during exposure. The groups exposed to peppermint were treated in a separate room from the group exposed to the control "odor."

The mice were weighed daily during exposure and were weaned at 21 days. At this time, they were caged individually and maintained on regular food (Charles River rat/mouse formula) and water until tested at 28 days. From Days 28-32, each animal was offered a daily diet of peppermint- and vanilla-flavored foods. These foods were made as follows: $200 \mathrm{~g}$ of regular diet was finely ground and $2 \mathrm{ml}$ of odorant (Frank's peppermint or Kroger's artificial vanilla) and water was added to it to produce a thick paste. This was differentially colored (green peppermint, red vanilla) using food coloring (Kroger's). The resulting colored paste was baked for approximately $1 \frac{1}{2} \mathrm{~h}$ in a moderate oven $\left(350^{\circ} \mathrm{F}\right)$. This yielded a compact, thoroughly flavored block which was easy to break but did not crumble.

Each animal received a weighed portion of both peppermint and vanilla daily, and its consumption of each flavor over the previous $24 \mathrm{~h}$ was recorded each day. The animals were weighed on the first and last day of testing.

\section{RESULTS}

The food-consumption data were analyzed using the Kruskal-Wallis analysis of variance and the MannWhitney $\mathrm{U}$ test. Mean daily consumption of each flavor is shown in Figure 1. On Days 2 and 3, both peppermintexposed groups showed a higher preference for peppermint-flavored diet than did the controls (i.e., a higher peppermint-consumption:total-consumption ratio). No significant differences were seen on Day 1 , Day 4, or Day 5. Details were as follows: Day $1, \mathrm{H}=$ $1.11, \mathrm{p}>.05 ;$ Day $2, \mathrm{H}=12.9, \mathrm{p}<.01(\mathrm{ZP} / \mathrm{ZC}, \mathrm{U}=2.5$, $\mathrm{p}=.001 ; \mathrm{ZP} / \mathrm{UP}, \mathrm{U}=24, \mathrm{p}>.05 ; \mathrm{ZP} / \mathrm{UC}, \mathrm{U}=4, \mathrm{p}=$ $.003 ; \mathrm{ZC} / \mathrm{UP}, \mathrm{U}=10, \mathrm{p}=.01 ; \mathrm{ZC} / \mathrm{UC}, \mathrm{U}=24.5, \mathrm{p}>$ .05 ; UP/UC, $\mathrm{U}=11, \mathrm{p}=.027)$; Day $3, \mathrm{H}=9.87, \mathrm{p}<$ $.02(\mathrm{ZP} / \mathrm{ZC}, \mathrm{U}=13, \mathrm{p}=.047 ; \mathrm{ZP} / \mathrm{UP}, \mathrm{U}=22, \mathrm{p}>.05$; $\mathrm{ZP} / \mathrm{UC}, \mathrm{U}=3.5, \mathrm{p}=.003 ; \mathrm{ZC} / \mathrm{UP}, \mathrm{U}=18, \mathrm{p}=.08$; 


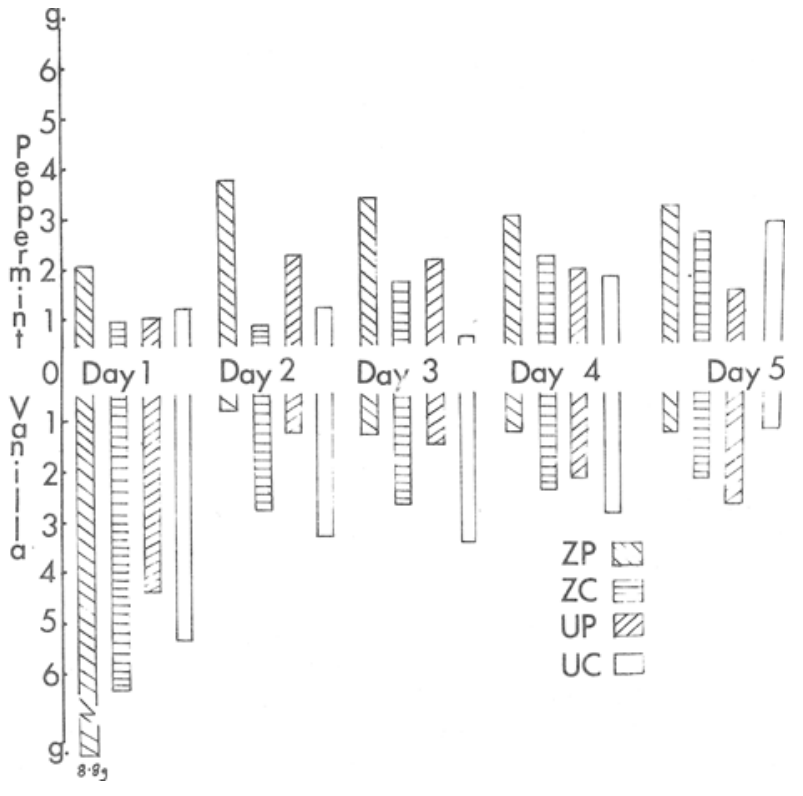

Figure 1. Mean daily consumption of peppermint- and vanilla-flavored diet.

$\mathrm{ZC} / \mathrm{UC}, \mathrm{U}=19, \mathrm{p}=.168 ; \mathrm{UP} / \mathrm{UC}, \mathrm{U}=6, \mathrm{p}=.005)$; Day $4, \mathrm{H}=3.41, \mathrm{p}>.05$; Day $5, \mathrm{H}=1.86, \mathrm{p}>.05$. We regard the results for Day 1 as unreliable. The vanilla diet given to some animals was not properly baked, and the resulting brownie-like substance was eaten greedily by all animals which received it.

Figure 2 shows the daily weight changes during exposure. Both zinc-sulfate-treated groups lost weight relative to the controls, but during testing all animals gained weight, and on the final day of testing there were no significant differences between the groups.

\section{DISCUSSION}

The results of the experiment indicate that the diet preference of 4-week-old mice can be modified by exposure to an odor for a limited period $(1 \mathrm{~h} /$ day $)$ during the third week of life, and this finding is in accordance with that of Leon et al. (1977).

The preference was not, however, long-lasting. On Day 1 the abnormal consistency of the vanilla-flavored diet led to a high preference for that flavor, but of the animals receiving correctly prepared diet, those exposed to peppermint showed a marked preference for it compared to the controls. A clear preference was found on Day 2 and Day 3, but not on the two remaining days. It is likely that the rules describing the effects of early exposure to a stimulus on the later attractiveness of the stimulus are complex; the biological significance of the stimulus, the length and timing of exposure, and the situation in which "testing" occurs may all be variables of importance.

It is not impossible that attraction toward biologically significant stimuli, to which preexposure has occurred, requires for its maintenance the array of reinforcements associated with speciestypical behavior. Attraction toward an arbitrary stimulus may be produced by preexposure, but then wanes as the stimulus' arbitrariness becomes apparent (i.e., responses toward it fail to be differentially reinforced).

The mice treated with zinc sulfate solution showed growth curves markedly different from the controls during the 6 days of exposure (see Figure 2), although on the final day of testing

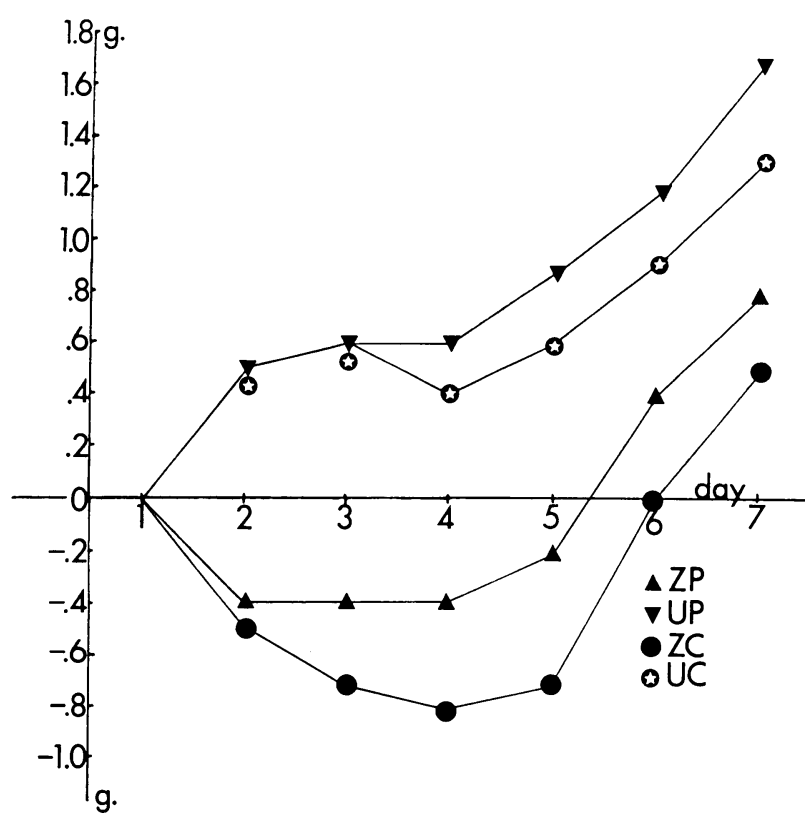

Figure 2. Weight changes during exposure (Days 1-6 after treatment).

(Day 32) there were no significant differences in weight between the groups. The failure to gain weight after treatment with 3\% zinc sulfate solution at Day 14 is associated with an olfactory deficit (Cooper \& Sosenko-Petro, Note 1). Group ZP, however, showed a strong preference for peppermint, and examination of Figure 1 suggests that this was greater (though not significantly so) than the preference of Group UP.

More work will be required to investigate the degree of anosmia produced by $2 \% \mathrm{ZnSO}_{4}$, the period of anosmia produced, and the relationship between length of exposure and strength and duration of preference.

\section{REFERENCE NOTE}

1. Cooper. A. J., \& Sosenko-Petro, M. The effects of intranasal zinc sulphate treatment on the grow'th and behavior of young mice. In preparation.

\section{REFERENCES}

Alberts. J. R.. \& Galef, B. G.. JR. Acute anosmia in the rat: A behavioral test of a peripherally-induced olfactory deficit. Physiology and Behavior. 1971, 6, 619-621.

CartTer. C. S.. \& Marr. J. N. Olfactory imprinting and age variables in the guinea pig Cavia porcellus. Animal Behaviour. 1970, 18. 238-244.

Leon. M.. Galef, B. G.. JR., \& Behse, J. H. Establishment of pheromonal bonds and diet choice in young rats by odor preexposure. Physiology \& Behavior. 1977, 18. 387-391.

Mainardi. D.. Marsan. M.. \& Pasquali, A. Causation of sexual preferences in the house mouse. The behavior of mice reared by parents whose odor was artificially altered. Atti della Societá italiana di Scienza naturali. 1965, 104, 325-338.

MARR. J. N.. \& GARDNER, L. E. Early olfactory experience and later social development in the rat: Preference, sexual responsiveness and care of young. Journal of Genetic Psychology, 1965. 107. 167-174.

Porter. R. H.. \& Etscorn, F. Olfactory imprinting resulting from brief exposure in Aconys cahirinus. Nature, 1974, 250. $732-733$.

(Received for publication July 18, 1977.) 